\title{
CONCENTRATION OF LIQUID PES MEDIA ON THE GROWTH AND PHOTOSYNTHETIC PIGMENTS OF SEAWEEDS COTONII PROPAGULE (KAPPAPHYCUS ALVAREZII DOTY) THROUGH TISSUE CULTURE
}

\author{
Lumbessy Salnida Yuniarti ${ }^{1,3 *}$, Andayani Sri ${ }^{2}$, Nursyam Happy ${ }^{2}$, Firdaus Muhammad ${ }^{2}$ \\ ${ }^{1}$ Graduate School, University of Brawijaya, Indonesia \\ ${ }^{2}$ Faculty of Fisheries and Marine Studies, University of Brawijaya, Indonesia \\ ${ }^{3}$ Marine Cultivation Study Program, University of Mataram, Indonesia \\ *E-mail: alyachali@gmail.com
}

\begin{abstract}
In vitro tissue culture of Kappaphycus alvarezii, the required nutrients are derived from the culture medium. The use of liquid PES medium as a culture medium has been widely applied to increase the growth rate of seaweeds. Seaweeds growth is also associated with photosynthetic pigments. If the absorption of light by chlorophyll a is sufficient, the process of photosynthesis will take place optimally, so that the growth of seaweed can increase. This study aims to examine the effect of liquid PES medium on the growth and photosynthetic pigments of Kappaphycus alvarezii propagule. The treatments used included $10 \mathrm{ml}$ and 20 $\mathrm{ml}$ liquid PES media. Parameters measured include weight gain, daily growth rate, photosynthetic pigment contents (chlorophyll a and phycoerythrin) and absorption of nitrate $(\mathrm{N})$ and phosphorus $(\mathrm{P})$. The results showed that the use of $10 \mathrm{ml}$ liquid PES medium gave better results than the use of $20 \mathrm{ml}$ liquid PES medium on all parameters measured.
\end{abstract}

\section{KEY WORDS}

Growth, photosynthetic pigments, K.alvarezii, tissue culture.

Every living creature, including small creature seaweed, requires both macro element and microelement nutrients to live and grow. In the real habitat, seaweed obtains nutrients from sea water containing various chemical components. In addition, seaweed also gains the nutrients from organic materials flown by the ocean. In order to survive in vitro cultures, cultivation media that serves as a provider of nutrients of the seaweed should contain the nutrients needed by the seaweed. In various types of algae, liquid PES media have been widely reported to be excellent for callus morphogenesis (Reddy et al., 2003; Munoz et al., 2006; Kumar et al., 2007; Baweja et al., 2009 \& Yong et al. 2011).

Studies on seaweed in vitro tissue culture, particularly on Eucheuma cottonii or $K$. alvarezii species in recent decades have provided new discoveries in seaweed cultivation, such as the discovery of improved varieties as seeds and better carrageenan production (Hayashi et al. 2008; Reddy et al.2008, Hurtado et al 2014, Yong et al 2014, \& Yong et al 2015). Meanwhile, some studies on metabolite and biological activities of macro algae also show that in addition to having polysaccharide content such as carrageenan and bioactive compounds, seaweed also contains other compounds namely pigments (Liu et al., 2005; Andersson et al., 2006; Schubert et al ., 2006; \& Indriatmoko et al., 2015).

Several studies on photosynthetic pigments in red seaweed have been conducted (Yocum \& Blinks, 1957; Saenger, 1969; Giuseppe \& Felicini, 1973; Mary \& Dawes 1981; Luning \& Schmitz, 1988; David \& Rowan, 1989; Ojala; 1993; Dagmar \& Mathew; 1998; Reeta \& Kulandaivelu; 2000; Aguilera et al., 2002; Gudrun and Wincke; 2005; Naguit \& Tisera; 2009; Sarojini \& Narayanan, 2009; Schmidt et al., 2010; Vanitha \& Chandra, 2012). However, most of the results of these studies only provide information about photosynthetic pigments with the limitation only to the cultivated red seaweed (in vivo), and no information about photosynthetic pigment in seaweed tissue culture (in vitro). Therefore, this research is intended to examine the extent to which liquid PES media as a tissue culture medium can give effect to the growth and content of photosynthetic pigments consisting of chlorophyll a and phycoerythrin on $K$. alvarezii propagule resulted from the tissue culture. 


\section{MATERIALS AND METHODS OF RESEARCH}

The materials used in this research are $K$. alvarezii callus in the form of micropropagules obtained from SEAMEO-BIOTROP in Bogor. Fertilizer used as a treatment is PES fertilizer obtained from the Tissue Culture Laboratory of Marine Aquaculture Hall Lombok.

Callus Acclimatization. Micropropagules obtained from SEAMEO-BIOTROP were firstly placed on the rotary shaker to be shaken for one week to adapt the culture. Rotary shaker was placed in the culture room with the room temperature between $22-25{ }^{\circ} \mathrm{C}$, given the irradiation of TL lamp with the light intensity was \pm 1500 lux, the duration of irradiation was set 12 hours on and 12 hours off.

In Vitro Culture. After the acclimatization of micropropagules placed on the rotary shaker, it was sub-cultured to a $1 \mathrm{~L}$ bottle containing liquid PES media with two treatments of $10 \mathrm{ml}$ and $20 \mathrm{ml}$ of PES in $500 \mathrm{~mL}$ of sterile seawater. The culture was aerated by aerator. After one week, the media was replaced with new media. The culture bottles were stored in the culture room with room temperature between $22-25{ }^{\circ} \mathrm{C}$, light intensity of \pm 1500 lux with the irradiation time of 12 hours on and 12 hours off. After six weeks, the volume of the PES media was added to $20 \mathrm{ml}$ of PES in 1 liter and $40 \mathrm{ml}$ of PES in 1 liter of sterile sea water. The cultivation of the micropropagules was performed for eight weeks (about 2 months).

Measurement of Propagule Growth. The measurements of propagule growth includes weight gain and daily growth rate which were measured every two weeks for two months of cultivation, using the formula proposed by Dawes et al. (1994). The weight gain was calculated based on the formula:

$$
\Delta \mathrm{W}=\mathrm{Wt}-\mathrm{Wo}
$$

Where: $\mathrm{Wt}=$ total weight of propagule at time of $\mathrm{t}(\mathrm{gram}) ; \mathrm{Wo}_{\mathrm{O}}=$ total initial weight of propagule (gram).

The daily growth rate was calculated based on the following formula:

$$
\alpha=\frac{\operatorname{Ln} W t-\operatorname{Ln} W o}{t} \times 100 \%
$$

Where: $\mathrm{W}_{\mathrm{t}}=$ final weight $(\mathrm{gram}) ; \mathrm{W}_{\mathrm{o}}=$ initial weight (gram); $\mathrm{t}=$ observation duration (days).

Measurement of Photosynthetic Pigments (Chlorophyll a and Phycoerythrin). The measurement of photosynthetic pigment includes the content of chlorophyll a and phycoerythrin. The measurements were taken every four weeks for eight weeks of cultivation. The samples of the seaweed were smoothed using a blender then weighed 2 gram and crushed using mortar. Samples were added with $10 \mathrm{ml} 100 \%$ acetone (for chlorophyll) and $10 \mathrm{ml} 0.1 \mathrm{M}$ phosphate buffer (for phycoerythrin). The samples were inserted in a test tube to be centrifuged and filtered. The centrifuged samples were measured on their absorbance by using a spectrophotometer at wavelengths of $664 \mathrm{~nm}$ and $647 \mathrm{~nm}$ for chlorophyll a and 592, 564 and $455 \mathrm{~nm}$ for phycoerythrin. Chlorophyll concentration was calculated based on the Sterman's equation (1988) while the concentration of phycoerythrin was calculated based on the Beer and Eshel equation (1985) as follows:

a) Chlorophyll a $=11.93\left(\mathrm{~A}_{664}\right)-1,93\left(\mathrm{~A}_{647}\right)$

$$
\text { b) Phycoerythrin }(\mathrm{mg} / \mathrm{L})=\left[\left(\mathrm{A}_{564}-\mathrm{A}_{592}\right)-\left(\mathrm{A}_{455}-\mathrm{A}_{592}\right) 0.20\right] \text { * } 0.12
$$

Furthermore, the concentration of pigment per gram of seaweed was calculated based on Naguit and Tisera equation (2009) as follow:

$$
\frac{\text { concentration }\left(\mathrm{mg} \cdot{ }^{\circ} \mathrm{L}\right) \times \text { solvent volume }(\mathrm{ml})}{\text { talus weight }(\mathrm{gr})} X \frac{1000 \mu \mathrm{g}}{\mathrm{mg}}
$$


Absorption of $N$ and $P$ on the Seaweed. Absorption of nitrogen and phosphorus by seaweed can be seen from the results of measurement of water quality and proximate analysis. Here are the formula to calculate the nitrogen and phosphorus absorbed by measuring the water quality proposed by Zhou et. al (2006):

$$
\begin{aligned}
& \mathrm{N} \text { uptake }(\mathrm{mg} / \mathrm{g})=\frac{\mid \mathrm{N}] \mathrm{t}-[\mathrm{N}] 0 \mid \times 1 \mathrm{~kg}}{W(g)} \\
& \mathrm{P} \text { uptake }(\mathrm{mg} / \mathrm{g})=\frac{\mid \mathrm{P}] \mathrm{t}-[\mathrm{P}] 0 \mid \times 1 \mathrm{~kg}}{W(g)}
\end{aligned}
$$

The absorption of nitrogen and phosphorus by the seaweed talus based on the results of proximate analysis with Kjeldahl method was calculated based on the equation of Zhou et. al (2006):

$$
\begin{aligned}
& \mathrm{N} \text { uptake }(\mu \mathrm{mol} / \mathrm{g} / \text { day })=\frac{\text { daily growth rate }(\% / \text { day }) \times \mathrm{N} \text { tissue }(\mathrm{g} / 100 \mathrm{~g})}{100} \\
& \mathrm{P} \text { uptake }(\mu \mathrm{mol} / \mathrm{g} / \text { day })=\frac{\text { daily growth rate }(\% / \text { day }) \times \mathrm{P} \text { tissue }(\mathrm{g} / 100 \mathrm{~g})}{100}
\end{aligned}
$$

Chemical and Physical Measurement of Water Quality. The measurements of the water quality were conducted every four weeks for eight weeks of the cultivation. The measurements were carried out physically which included some aspects, e.g. salinity, $\mathrm{pH}$, DO and temperature.

Data Analysis. The data related to the growth and photosynthetic pigment were analyzed by ANOVA variance analysis, while the $\mathrm{N}$ and $\mathrm{P}$ absorption data and water quality were integrated as the supporting data analyzed by using the mean and graph. Data processing through the graph was done with Microsoft Excel program

\section{RESULTS OF STUDY}

Micropropagule Growth. The observed weight gain of propagules during the 8 week cultivation increased along with longer duration for all treatments (Figure 1).

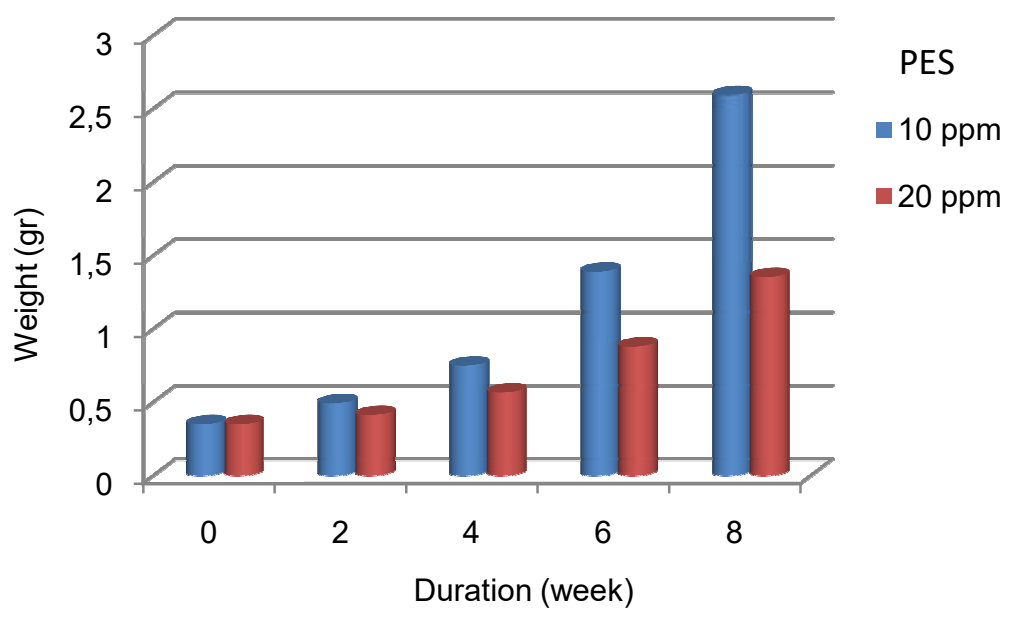

Figure 1 - The weight gain of $K$. alvarezii propagule in 8 weeks of cultivation

The treatment of $10 \mathrm{ml}$ liquid PES medium in $500 \mathrm{ml}$ of sterile seawater gave a better average on weight gain compared to the $20 \mathrm{ml}$ liquid PES medium treatment in the same $500 \mathrm{~mL}$ of sterile seawater. The highest average weight gain was obtained at $10 \mathrm{ml}$ liquid 
PES medium treatment, which was 2.24 gram, while the lowest average weight gain was in the $20 \mathrm{ml}$ liquid PES medium treatment, amounted to 1.00 gram (see Table 1).

Table 1 - The average weight gain of $K$. alvarezii propagule in various concentrations of liquid PES media

\begin{tabular}{cccc}
\hline Liquid PES $(\mathrm{ml})$ & Initial weight (gram) & Final weight (gram) & Absolute weight (gram) \\
\hline 10 & $0.35 \pm 0.02$ & $2.59 \pm 0.072$ & $2.24 \pm 0.073$ \\
20 & $0.35 \pm 0.01$ & $1.35 \pm 0.042$ & $1.00 \pm 0.035$ \\
\hline
\end{tabular}

This is also in line with the daily growth rate of propagules, in which the range of daily growth rate in the $10 \mathrm{ml}$ liquid PES medium treatment results in a higher yield of 2.42 $4.46 \%$ per day compared with the $20 \mathrm{ml}$ liquid PES medium treatment at the range of daily growth rate is $1.18-3.072 \%$ per day (see Figure 2).

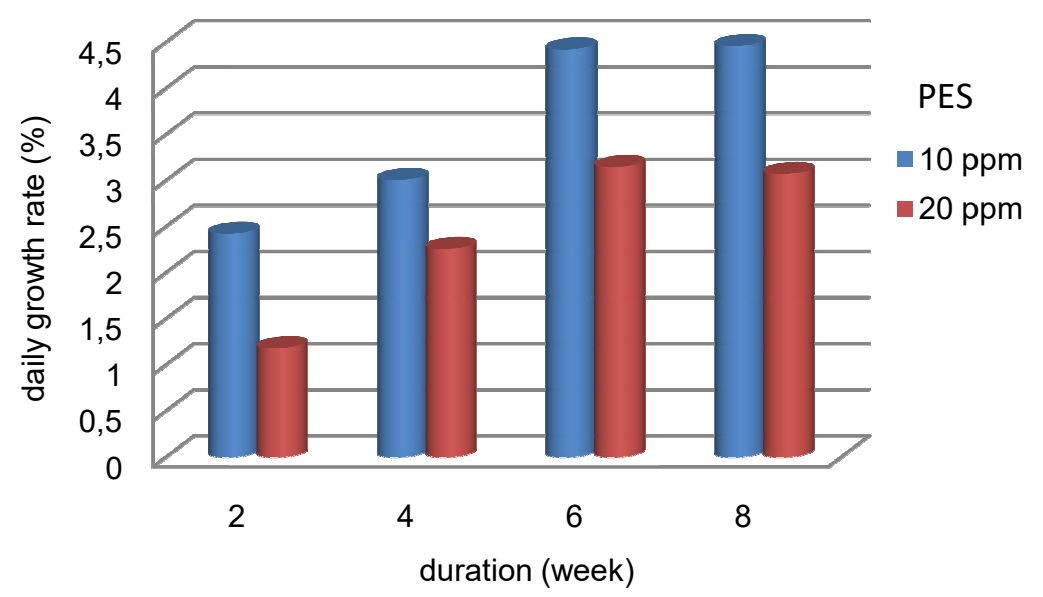

Figure 2 - Daily growth rate of $K$. alvarezii propagule in eight weeks of cultivation

The results of the variance analysis showed that the different concentration of the liquid PES media contribute very real effect ( $F$ statistic $>F$ table) to the daily growth rate of seaweed $K$. alvarezii propagule.

Photosynthetic Pigment Content. The results showed that the difference of concentration of liquid PES media give obvious effect ( $F$ statistic $>F$ table) to the photosynthetic pigment content of $K$. alvarezii propagule, both for chlorophyll a and phycoerythrin. The content of chlorophyll a on $K$. alvarezii propagule increases along with the increasing cultivation duration at all treatments (Figure 3). On the contrary, the phycoerythrin content decreases along with the increasing cultivation time at all treatments (Figure 4).

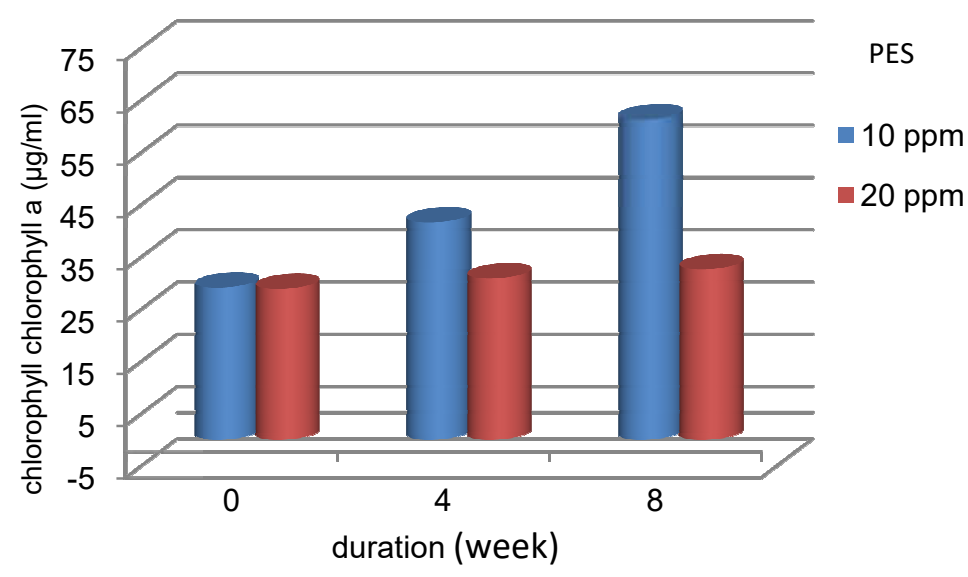

Figure 3 - Content of Chlorophyll a of $K$. alvarezii propagule in eight weeks of cultivation 


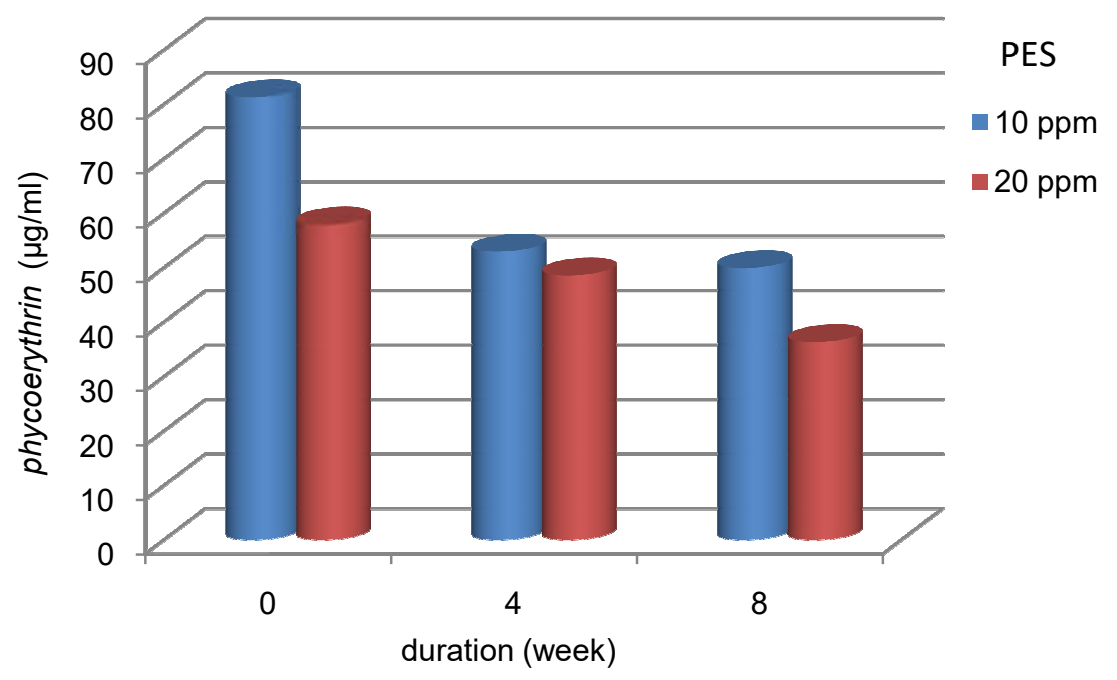

Figure 4 - Content of phycoerythrin a of $K$. alvarezii propagule in eight weeks of cultivation

At the end of the cultivation period (8 weeks), it was found that the $10 \mathrm{ml}$ liquid PES treatment in $500 \mathrm{ml}$ of sterile seawater gave chlorophyll a and phycoerythrin pigments of $61.308 \mu \mathrm{g} / \mathrm{ml}$ and $49.916 \mu \mathrm{g} / \mathrm{ml}$, respectively. On the other hand, the liquid PES medium treatment $20 \mathrm{ml}$ in $500 \mathrm{ml}$ of sterile seawater gives chlorophyll a and phycoerythrin content of $32.608 \mu \mathrm{g} / \mathrm{ml}$ and $36.314 \mu \mathrm{g} / \mathrm{ml}$ (Table 2), respectively.

Table 2 - The average content of chlorophyll and phycoerythrin of $K$. alvarezii propagule at several doses of liquid PES

\begin{tabular}{cccc}
\hline \multirow{2}{*}{ Liquid PES $(\mathrm{ml})$} & \multirow{2}{*}{ Duration of cultivation (week) } & \multicolumn{2}{c}{ Photosynthetic pigments $(\mu \mathrm{gg} / \mathrm{ml})$} \\
\cline { 3 - 4 } & & Chlorophyll a & phycoerythrin \\
\hline 10 & 4 & $29.102 \pm 0.575$ & $81.301 \pm 3.185$ \\
& 8 & $41.598 \pm 1.074$ & $52.961 \pm 2.501$ \\
& 0 & $61.308 \pm 0.330$ & $49.916 \pm 4.107$ \\
\hline 20 & 4 & $28.849 \pm 0.983$ & $57.925 \pm 1.203$ \\
& 8 & $30.866 \pm 0.093$ & $48.573 \pm 7.266$ \\
& 0 & $32.608 \pm 0.648$ & $36.314 \pm 0.989$ \\
\hline
\end{tabular}

$N$ and $P$ Absorption. Nitrogen in the waters is generally in the form of nitrate (NO2), nitrite (NO3) and ammonia (NH3), whereas the phosphorus in the waters is often abundant in various forms of phosphate compounds, including total phosphate (PO4). The results of calculations on the $\mathrm{N}$ and $\mathrm{P}$ absorption based on the water quality (Table 3 ) show that $K$. alvarezii propagules absorbs more nitrate than nitrites and ammonia.

Table 3 - The absorption of nitrate, nitrite, ammonia, and total phosphate by $K$. alvarezii propagule in different concentrations of liquid PES media

\begin{tabular}{ccc}
\hline Absorption $(\mathrm{mg} / \mathrm{g})$ & \multicolumn{2}{c}{ Liquid PES } \\
\cline { 2 - 3 } & $10 \mathrm{ml}$ & $20 \mathrm{ml}$ \\
\hline $\mathrm{NO}_{2}$ & 1.316602 & 0.332046 \\
$\mathrm{NO}_{3}$ & $*$ & 0.05405 \\
$\mathrm{NH}_{3}$ & 0.06564 & 0.42471 \\
$\mathrm{PO}_{4}$ & 0.5444 & \\
\hline
\end{tabular}

Note: * not detected.

The amount of nitrate absorbed in the $10 \mathrm{ml}$ liquid PES medium treatment showed the highest value of $1.316602 \mathrm{mg} / \mathrm{g}$, whereas in the treatment of $20 \%$ liquid PES medium showed the value of $0.332046 \mathrm{mg} / \mathrm{g}$. The absorbed nitrite cannot be detected because the nitrite content in waters $<0.01 \mathrm{mg} / \mathrm{L}$. Meanwhile, the ammonia absorbed in the $10 \mathrm{ml}$ liquid PES medium treatment also showed the highest value of $0.06564 \mathrm{mg} / \mathrm{g}$, whereas in the 
treatment of $20 \%$ liquid PES medium only absorbed $0.05405 \mathrm{mg} / \mathrm{g}$. In the result of calculations of the total phosphate showed that $K$. alvarezii propagule on treatment of $10 \mathrm{ml}$ liquid PES media absorbed the highest total phosphate absorption that is equal to 0.5444 $\mathrm{mg} / \mathrm{g}$, whereas in the treatment of $20 \mathrm{~mL}$ liquid PES medium was only able to absorb the total phosphate equal to $0.42471 \mathrm{mg} / \mathrm{g}$.

The results of calculations on the $\mathrm{N}$ and $\mathrm{P}$ uptake based on the proximate analysis show that the $K$. alvarezii propagule in the $10 \mathrm{ppm}$ liquid PES medium treatment was capable of absorbing the highest nitrogen and phosphorus, i.e. $0.16 \mu \mathrm{mol} / \mathrm{g}$ per day and 0.03 $\mu \mathrm{mol} / \mathrm{g}$ per day, while for the $K$. alvarezii propagule with $20 \mathrm{ppm}$ liquid PES medium treatment was only able to absorb nitrogen and phosphorus of $0.11 \mu \mathrm{mol} / \mathrm{g}$ per day and $0.017 \mu \mathrm{mol} / \mathrm{g}$ per day respectively.

Parameters of Water Quality. The results of measurement of the water quality during the eight weeks of cultivation can be seen in Table 4.

Table 4 - Parameters of Water Quality

\begin{tabular}{|c|c|c|c|c|}
\hline \multirow[b]{2}{*}{ No. } & \multirow[b]{2}{*}{ Parameters } & \multicolumn{2}{|c|}{ Range of observation } & \multirow[b]{2}{*}{ References } \\
\hline & & Liquid $10 \mathrm{~mL} P E S$ & $20 \mathrm{~mL}$ Liquid PES & \\
\hline 1 & Temperature $\left({ }^{\circ} \mathrm{C}\right)$ & $22.18-26.81$ & $23.5-26.12$ & $\begin{array}{c}22-33 \\
\text { (Lideman et al., 2013). }\end{array}$ \\
\hline 2 & Acidity $(\mathrm{pH})$ & $7.87-8.67$ & $8.13-8.17$ & $\begin{array}{c}6-8 \\
\text { (Semedi et al., 2016) }\end{array}$ \\
\hline 3 & DO (mg/L) & $5.03-5.3$ & $5.15-5.46$ & $\begin{array}{c}5-8 \\
\text { (Semedi et al., 2016) }\end{array}$ \\
\hline 4 & Salinity (ppm) & $33-34.2$ & $36.2-38.8$ & $\begin{array}{c}30-35 \\
\text { (Dawes, 1981) }\end{array}$ \\
\hline
\end{tabular}

\section{DISCUSSION OF RESULTS}

PES fertilizer is a complete fertilizer as it contains macronutrient and micronutrient elements which are very complete and needed by seaweeds. Reddy et al., reported that PES is typical fertilizer which is widely used for algae growth because of its complete nutrients contents and suitable for algae species, especially seaweed at the enlargement of the talus up to $3-5 \mathrm{~cm}$ in size. Mansilla et al., (2007) stated that during the cultivation of seaweed seeds in the laboratory, fertilizers containing macronutrients (nitrogen, phosphorus, potassium) and micronutrients (Mo, Ni, Mn, B, Cu, Zn, Co, Cl, and $\mathrm{Na}, \mathrm{S}$ ), give higher growth rates on the seaweed compared to fertilizers containing only macronutrients.

The results of this study indicate that in general the $10 \mathrm{ml}$ liquid PES medium gives the highest average weight of $K$. alvarezii propagule (Table 1 ) compared to the $20 \mathrm{ml}$ liquid PES medium. This indicates that the nutrient content of $10 \mathrm{ml}$ liquid PES medium is more suitable for the growth of $K$. alvarezii propagule cells. The absorption of nutrients contained in a $10 \mathrm{ml}$ liquid PES medium can be utilized well by propagule through optimal water movement by aeration. Lobban \& Harrison (1994) state that water movement is a factor affecting the growth of $K$. alvarezii because the movement or current plays an important role in improving nutrient exchange conditions and avoiding deposition to support growth which is also a means of nutrient transport. Water movement serves to supply nutrients and clean the dirt on the surface of the talus.

The high growth of $K$. alvarezii propagule in the $10 \mathrm{ml}$ liquid PES medium treatment was also supported by the high average of daily growth rate of $3.58 \%$ per day compared with the treatment of $20 \mathrm{ml}$ liquid PES medium with the average daily growth rate is $2.41 \%$ per day (Figure 2). The value of daily growth rate in the treatment of $10 \mathrm{ml}$ PES medium is quite good considering that growing rate of cottonii seaweed at the time being cultivated in the nature ranges from 3-5\% depending on the season (Thirumaran \& Anantharaman, 2009). Young et al (2011) stated that in in vitro micro-propagation type Eucheuma sp., daily growth rate on PES medium is higher than von Stosch, F/2 and sea water media. Further, the results of Sulistiani, et al (2011) showed that the daily growth rate of propagule at $20 \mathrm{ml} / \mathrm{L}$ liquid PES was not significantly different with the concentration of $10 \mathrm{ml} / \mathrm{L}$ liquid PES, but the 
second growth rate treatment was higher and significantly different with growth rate at $5 \mathrm{ml} / \mathrm{L}$ treatment. For the purpose of efficient use of chemicals, then in the enlargement of propagules should not always use the concentration of $20 \mathrm{ml} / \mathrm{L}$, but also the use of the concentration of $10 \mathrm{ml} / \mathrm{L}$ PES.

Treatment with $10 \mathrm{ml}$ liquid PES medium was not only to give the best weight gain and daily growth rate, but also provide better photosynthetic pigment (chlorophyll a) (see Table 2). Lobban \& Harrison (1994) stated that sunlight directly affects the absorption of nutrients, active transport and increases the growth rate of the seaweeds. The sunlight through the photosynthesis process is able to release some energy, and this energy is used by ions and elements to pass through the cell membrane of the plants. At the time the ions enters, the ions function according to their respective functions, such as enzyme cofactors, enzyme activators, and general work of other ions. In addition, the elements that enter the cell will carry some energy.

The process of photosynthesis in the seaweeds not only utilizes chlorophyll pigment, but there are other accessories or complementary pigments, namely phicobillyprotein (Rphicocyanin, allophicosianin and phycoerythrin), (Aguirre et al., 2001; Naguit \& Tisera, 2009; Zhao \& He, 2009; Chakdar et al., 2012; Pugalendren et al., 2012). The complementary pigments analyzed in this study were phycoerythrin pigment. Based on the average value indicates that the content of phycoerythrin pigment inversely proportional to chlorophyll a. The higher content of phycoerythrin pigment at the beginning of cultivation is presumed as the amount of chlorophyll a is still low, so that it is insufficient in the absorption of light for the process of photosynthesis; this triggers the formation of more phycoerythrin (Kawsar et al, 2011; Pumas et al., 2012). Phycoerythrin is a protein that acts as a complementary pigment in red algae and blue-green algae that serves to help chlorophyll-a in absorbing light in the process of photosynthesis. The light absorbed by phycoerythrin is efficiently transferred to phycocyanine, then to allophycocyanine and to allophycocyanine $\mathrm{B}$, and finally goes to the chlorophyll (Bryant, 1982; Chakdar et al. 2012; Pugalendren et al., 2012).

The increased weight and higher chlorophyll content during the $10 \mathrm{ml}$ liquid PES medium treatment was believed to be strongly influenced by the nutrient content of the culture medium. In general, seaweed growth is closely related to photosynthetic pigment content, i.e. chlorophyll a. If the absorption of the light by chlorophyll a is sufficient, the process of photosynthesis may occur optimally which in turn affects the faster growth rate of the seaweeds. Therefore any growth process and pigment formation will require nutrients. The most important and indispensable nutrients needed by seaweed are nitrogen $(N)$ and phosphorus (P). Harrison and Hurd (2001) state that the growth and development of the seaweed requires sufficient light and quality nutrients such as nitrate and phosphate. Nitrates and phosphates are needed as the basic ingredients of protein constituents and the formation of chlorophyll in the process of photosynthesis. In relation with the tissue culture activities, nitrate and phosphate can be derived from the culture medium. The results of study carried out by Dong et al. (1990) showed that the provision of $\mathrm{N}$ in the seaweed Laminaria japonica can increase the amount of chlorophyll a. Kim et al., (2007) states that the synthesis of chlorophyll a and phycoerythrin requires $\mathrm{N}$ as well.

The nutrients ( $N$ and $P$ ) enter into the body of seaweed by diffusion through the entire surface of the body of the plant. The absorption of nutrients through the diffusion process is supported by the movement of water in the aeration-assisted cultivation medium. Lobban \& Harrison (1994) asserted that the elements in the waters will enter into the algae through the process of absorption, diffusion, and osmosis; there should be the balance of ions and elements between the outside and inside of the cells. The more diffusion takes place, it will accelerate the metabolism process, thus increasing the growth rate of the seaweeds.

Nitrogen and Phosphorus is a mineral nutrient that limits plant growth due to its large availability in media (Harrison \& Hurd, 2001; Harpole et al 2011). The results of this study indicate that $10 \mathrm{ml}$ liquid PES medium also provides the most nutrient absorption of nitrate and total phosphate (Table 3 ). After the proximate analysis was conducted, it was shown that $K$. alvarezii propagule in the $10 \mathrm{ml}$ PES liquid medium treatment was the most nitrogen and phosphorus-containing seaweeds in the body that could be used for the faster growth. The 
more seaweed absorbs nitrogen and phosphorus, the greater the amount of nitrogen and phosphorus contained in the seaweed, and this indicates that the better quality.

The absorption rate of nitrate and phosphate has a positive correlation with the increasing growth rate as well as synthesis of chlorophyll a and phycoerythrin (Dong et al., 1990; Gordillo et al. 2002; Kim et al., (2007). Lea and Azevedo (2006) stated that growth may occur as the result of the function of nitrate as an ingredient of protein. It is presumably the protein has potential to activate the enzymes in the plant body; it will change the substrate into new products as the result of duplication or multiplication of cells. The bigger amount of Nitrogen in plants may cause the bigger formation of glutamic acid. Initially nitrogen is absorbed is in the form of ammonia, and then ammonia change to glutamic acid, catalyzed by enzyme glutamine synthase. Glutamic acids serve as the base material in biosynthesis of amino acid and nucleic acid. Glutamic acid will form acid aminolevulinate (ALA) which acts as a porphyrinin precursor ring in the formation of chlorophyll. Therefore, the amount of nitrogen content can affect photosynthesis results through photosynthetic enzyme and chlorophyll content (Robinson 1995, Lea \& Miflin, 2003; Suzuki \& Knaff, 2005; Yaronskaya et al., 2006)

In addition to nitrate, phosphate is also a major nutrient factor to meet the needs of algae. Phosphate is a component that plays a role in the formation of DNA, lipid and energy metabolism, such as ATP and NADPH. The production of ATP and NADPH through a light reaction to the photosynthesis process will produce the energy to be used in the Calvin cycle to phosphorylate and convert 3-phosphoglycerate (PGA) to Glyceraldehyde 3-phosphate (G3P) and regenerate Ribulose 1.5-bisphosphate (RuBP) (Farguhar et al., 1980; Reich et al., 2009). The content of phosphorus in algae cells affects phosphate uptake, which is reduced in line with increased phosphate content in cells. Several types of algae are able to absorb the phosphate beyond their needs (luxury consumption) and are able to absorb phosphates at very low concentrations and have alkaline phosphatase enzymes that can convert phosphates into orthophosphate ready to use (Sahoo \& Ohno, 2001).

Although nitrate and phosphate are essential for the growth and process of plant photosynthesis, plants need only this element in sufficient quantities. Therefore, based on the results of this study, it is believed that the $10 \mathrm{ml}$ liquid PES medium provides sufficient $\mathrm{N}$ and $\mathrm{P}$ elements for the growth and photosynthesis process of $K$. alvarezii propagules. As the concentration of liquid PES media was raised to $20 \mathrm{ml}$, the growth and the photosynthesis rate decreased. This suggests that increased concentrations of nutrients above optimal requirements will not increase the growth of the plant. This is in line with Knecht and Göransson's (2004) opinion that plants require a certain minimum concentration of nutrients to grow, and when nutrient concentration rises to optimum levels, it increases the relative growth rate. The increased concentrations of nutrients above the optimum will not increase growth, and at very high concentrations the nutrients even will become toxic, the growth and the rate of photosynthesis will decrease, and the plant may die.

Besides supported by the nutrients, the growth rate may increase if the media and the environment around the cultivation are in accordance with needs or tolerable ranges. Aks and Azansa (2002) stated that environmental factors that have an important role in the cultivation of $K$. alvarezii such as temperature, salinity, nutrition, light and several other ecologic factors. The water quality that has been measured during the cultivation indicates a value that is still in the good and tolerable range (Table 4.)

\section{CONCLUSION}

The results of this study indicate that the use of $10 \mathrm{ml}$ liquid PES medium gives higher weight gain, better daily growth rate and better photosynthetic pigment content (chlorophyll a and phycoerythrin) than the use of $20 \mathrm{ml}$ liquid PES medium for the seaweed $K$. alvarezii propagule through tissue culture. It is believed that the $10 \mathrm{ml}$ liquid PES medium provides the optimum $\mathrm{N}$ and $\mathrm{P}$ elements for the growth and photosynthesis process of $K$. alvarezii propagules. 


\section{REFERENCES}

1. Aguirre, E., F.L. Figueroa and A.C. Pasini. 2001. Photosynthesis and Growth of Red and Green Morphotypes of Kappaphycus alvarezii (Rhodophyta) from the Philippines. Marine Biology, 138: 679-686.

2. Andersson, M., H. Schubert, M. Pedersen and P. Snoeijs. 2006. Different Patterns of Carotenoid Composition and Photosynthesis Acclimation in Two Tropical Red Algae. Marine Biology, 149: 653-665.

3. Aguilera, J., K. Bischof, U. Karsten, D. Hanelt and C. Wiencke. 2002. Seasonal Variation in Ecophysiological Patterns in Macroalgae from an Arctic Fjord. II. Pigment Accumulation and Biochemical Defence Systems Against High Light Stress. Marine Biology, 140: 1087-1095.

4. Ask, E. I. and V. R. Azanza. 2002. Advances in Cultivation Technology of Commercial Eucheumatoid Species: A Review with Suggestions For Future Research. Journal of Aquaculture, 206: 257-277.

5. Baweja, P. D., P. Sahoo, J. Garcia and R. R. Robaina. 2009. Seaweed Tissue Culture as Applied to Biotechnology: Problems, Achievements and Prospects. Phycological Research, 57: 45-58.

6. Beer, S., and A. Eshel. 1985. Determining Phycoerythrin and Phycocyanin Concentrations in Aqueous Crude Extracts of Red Algae. Marine and Freshwater Research, 36: 785-792

7. Bryant, D. A., 1982. Phycoerythrocyanin and Phycoerythrin: Properties and Occurrence in Cyanobacteria. Journal of General Microbiology, 128: 835-844.

8. Chakdar, H., S. Pabbi. 2012. Extraction and Purification of Phycoerythrin from Anabaena variabilis (CCC421). Phykos, 42 (1): 25-31.

9. Czeczuga, B. 1985. Light Harversting Phycobiliprotein Pigments of the Red Alga Leptosomia simplex from the Antarctic. Polar Biology, 4(3): 179-181.

10. Dagmar, B. S. and J. D. Mathew. 1998. Seasonal Variation in the Pigment Content and Photosynthesis of Different Thallus Regions of Ascophylleum nodosum (Fucales, Phaeophyta) in Relation to Position in the Canopy. Phycologia, 37(4): 259-268.

11. David, R. A. H. and K. S. Rowan. 1989. The Biliproteins of the Cryptophyceae. Phycologia, 28(4): 453-463.

12. Dawes, C. J. 1981. Marine Botany. John Wiley and Sons University of South Florida. New York.

13. Dawes, C. J., A.O. lluisma, G. C. Trono. 1994. Laboratory and Field Growth Studies of Commercial Strains of Eucheuma denticulatum and Kappaphycus alvarezii in the Philippines. Journal of Applied Phycology. 6: 21-24

14. Dong, L., L. Guangheng and W. Chaoyuan. 1990. Effect of $\mathrm{NH}_{4} \mathrm{~N}$ on the Pigment Content of Laminaria Japonica. Chinese Journal of Oceanology and Limnology. 8 (2): 128-134.

15. Farquhar, G. D., S. V Caemmerer and J. A. Berry. 1980. A Biochemical Model of Photosynthetic $\mathrm{CO}_{2}$ Assimilation in Leaves of c3 Species. Planta, 147: 78 - 90.

16. Giuseppe, C. and G. P. Felicini. 1973. Research on Red Algal Pigments. 5. The Effect of the Intensity of White and Green Light on the Rate of Photosynthesis and its Relationship to Pigment Components in Gracilaria compressa (C.Ag.) Grev. (Rhodophyceae, Gigartinales). Phycologia, 12(3): 195-198.

17. Gordillo, F.J.L., M.J. Dring, and G.Savidge, 2002. Nitrate and Phosphate Uptake Characteristics of Three Species of Brown Algae Cultured at Low Salinity. Marine Ecology Progress Series, 234: 111-118.

18. Gudrun, K., and C. Wincke. 2005. Photosynthesis, Photosynthetic Pigment and Mycosporine-Like Aminoacids After Exposure of the Marine Red Alga Chondrus crispus (Gigartinales, Rhodophyta) to Different Light Qualities. Phycologia, 44(1): 95-102.

19. Harpole, W. S., J. T. Ngai, E. E. Cleland, E. W. Seabloom, E. T. Borer, M. E. S. Braken, J. J. Elser, D. S. Gruner, H. Helmut, J. B. Shurin, and J. E. Smith. 2011. Nutrient CoLimitation of Primary Producer Communities. Ecology Letters, 14: 852-62. 
20. Hayashi, L., N. S. Yokoya, D. M. Kikuchi and E. C. Oliveira.2008. Callus Induction and Micropropagation Improved by Colchicine and Phytoregulators in Kappaphycus alvarezii (Rhodophyta, Solieriaceae). Journal of Applied Phycology, 20: 653-659

21. Harrison, P. J., and C. L. Hurd. 2001. Nutrient Physiology of Seaweeds: Applications of Concepts to Aquaculture. Cahiers de Biologie Marine, 42: 71-82

22. Hurtado, A., R. Reis, R. Loureiro, and A. Critchley. 2014. Kappaphycus (Rhodophyta) Cultivation: Problems and the Impacts of Acadian Marine Plant Extract Powder. In: Pereira L, Neto JM (eds) Marine Algae. CRC Press, Boca Raton, pp: 251-299

23. Indriatmoko, Heriyanto, L. Limantara, and T. H. P. Brotosudarmo. 2015. Composition of Photosynthetic Pigments in A Red Alga Kappaphycus alvarezi Cultivated in Different Depths. Procedia Chemistry, 14: 193-201

24. Kawsar, S., F.Yuki, M. Ryo, Y. Hidetaro and O. Yasuhiro. 2011. Protein R-phycoerythrin from Marine Red Alga Amphiroa anceps: Extraction, Purification and Characterization. Phytologia Balcanica, 17(3): 347-354.

25. Kim, J. K., G. P. Kreamer, C. D. Neefus, I. K. Chung and C. Yarish. 2007. Effect of Temperature and Ammonium on Growth, Pigment Production and Nitrogen Uptake by Four Species of Porphyra (Bangiales, Rhodophyta) Native to The New England Coast. Journal of Applied Phycology, 19: 431-440.

26. Knecht, F. M and A. Göransson. 2004. Terrestrial Plants Require Nutrients in Similar Proportions. Tree Physiology 24: 447-460

27. Kumar, G. R., C. R. K. Reddy, and B. Jha. 2007. Callus Induction and Thallus Regeneration From Callus of Phycocolloid Yielding Seaweeds from the Indian Coast. Journal of Applied Phycology,19: 15-25.

28. Lea, P. J. and R. A. Azevedo. 2006. Nitrogen Use Efficiency. 1. Uptake of Nitrogen from the Soil. Annals of Applied Biology 149 (3): 243-247.

29. Lea, P. J. and B. J. Miflin. 2003. Glutamate Synthase and The Synthesis of Glutamate in Plants. Plant Physiology and Biochemistry, 41: 555-560.

30. Lideman, G. N. Nishihara, T. Noro and R. Terada. 2013. Effect of Temperature and Light on the Photosynthesis as Measured by Chlorophyll Fluorescence of Cultured Eucheuma denticulatum and Kappaphycus sp. (Sumba Strain) from Indonesia. Journal of Applied Phycology, 25(2): 399 - 406

31. Liu, L.N., X. L. Chen, Y. Z. Zhang and B. C. Zhou. 2005. Characterization, Structure and Function of Linker Polypeptides in Phycobilisomes of Cyanobacteria and Red Algae: An Overview. Biochimica et Biophysica Acta (BBA)-Bioenergetics, 1708 (2): 133-142.

32. Lobban, C.S. and P.J. Harrison. 1994. Seaweed Ecology and Physiology. Cambridge University Press, Australia.

33. Luning, K. and K. Schmitz. 1988. Dark Growth of the Red Alga Delesseria sanguine (Ceramiales): Lack of Chlorophyll, Photosynthetic Capability and Phycobilisomes. Phycologia, 27(a): 72-77

34. Mansilla A., M. Palacios, N. P. Navarro, and M. Avila. 2008. Growth and Survival Performance of the Gametophyte of Gigartina skottsbergi (Rodophyta, Gigartinales) Under Defined Nutrient Conditions in Laboratory Culture. Journal of Applied Phycology, 20(5): $889-896$.

35. Mary, A. D. and C. J. Dawes. 1981. Seasonal Photosynthetic and Respiratory Responses of the Intertidal Red Alga, Bostrychia binderi Harvey (Rhodophyta, Ceramiales) from a Mangrove Swamp and a Salt Marsh. Phycologia, 20(2): 165-173.

36. Muñoz J., A. C. Cahue-López, R. Patiño and D. Robledo. 2006. Use of Plant Growth Regulators In Micropropagation of Kappaphycus alvarezii (Doty) in Airlift Bioreactors. Journal of Applied Phycology, 18: 209-18.

37. Naguit, M. R. A. and W. L. Tisera. 2009. Pigment Analysis on Eucheuma denticulatum (Collins \& Hervey) and Kappaphycus alvarezii (doty) Cultivars Cultured at Different Depths. Threshold, 4: 29-37.

38. Ojala, A.1993. The Influence of the Quality on Growth And Phocobiliprotein/Chlorophyll a Flurescence Quotients of Some Species of Freshwater Algae in Culture. Phycologia, 32(1): 22-28. 
39. Pangestuti, R. and S. K. Kim. 2011. Biological Activities and Health Benefit Effects of Natural Pigments Derived from Marine Algae. Journal of Functional Foods, 3(4): 255-266.

40. Paul, L., W. M. Jones, and J. Woelkerling.1983. Some Effects of Light and Temperature and Conceptacle Production in Fosliella cruciata Bressan (Corallinaceae, Rhodophyta). Phycologia, 22(4): 449-452.

41. Pereira, D.C., T. G. Trigueiro, P. Colepicolo, and E. M. Soriano. 2012. Seasonal Changes in the Pigment Composition of Natural Population of Gracilaria domingensis (Gracilariales, Rhodophyta). Brazillian Journal of Pharmacognosy, 22: 874-880.

42. Pugalndren S., B. Sarangam, and R. Rengasamy. 2012. Extraction of R-Phycoerythrin from Kappaphycus alvarezii (Doty) Doty ex Silva and Analyses of its Physico-Chemical Properties. Youth Education and Research Trust (YERT), 1(7): 407-411

43. Pumas C., Y. Peerapornpisal, P. vacharapiyasophon, P. Leelapornpisid, W. Boonchum, M. Ishii, and C. Khanongnuch. 2012. Purification and Characterization of a Thermostable Phycoerythrin from Hot Spring Cyanobacterium Leptolyngbya sp. International Journal of Agriculture \& Biology, 14: 121-125.

44. Reddy, C. R. K., G. R. K. Kumar, A. K. Siddhanta, and A. Tewari, 2003. In Vitro Somatic Embriogenesis and Regeneration of Somatic Embryos from Pigmented Callus of Kappaphycus alvarezii (Doty) Doty (Rhodophyta, Gigartinales). Journal of Phycology, 39: 610-616

45. Reddy, C. R. K., B. Jha, Y. Fujita, and M. Ohno. 2008. Seaweed Micropropagation Techniques and Their Potentials: An Overview. Journal of Applied Phycology, 20: 609617

46. Reeta, J and G. Kulandaivelu. 2000. Effect of Light Intensity on the Saturation of Photosynthesis in Gracilaria Species (Rhodophyta). Seaweed Research Utilization, 22(1\&2): 31-35.

47. Reich, P. B., O. Jacek, J. W. Ian. 2009. Leaf Phosphorus Influences the PhotosynthesisNitrogen Relation: a Crossbiome Analysis of 314 Species. Oecologia, 160: $207-212$ Robinson, D. 1994. The responses of Plants to Non-Uniform Supplies of Nutrients. New Phytologist 127: 635-674.

48. Saenger, P. 1969. The Water Soluble Pigments of the Red Algae, Lenormandia prolifera. Phycologia, 7(1): 59-63.

49. Sahoo, D. and M. Ohno 2001. Deep Seawater-New Area of Research and Utilization in 21st Century. Journal of Indian Ocean Studies, 9: 282-286.

50. Sarojini Y. K., and L. Narayanan. 2009. Influence of Environmental Factors on Variations in Distribution of Photosynthetic Pigments of Macro Algae. Algal Biomass, Resources and Utilization: 157-163.

51. Schmidt, E. C., B. G. Nunes, M. Maraschin, and Z. L. Bouzon. 2010. Effect of UltravioletB Radiation on Growth, Photosynthetic Pigment, and Cell Biology of Kappaphycus alvarezii (Rhodophyta, Gigartinales) Macroalgae Brown Strain. Photosynthetica, 48(2): 161-172.

52. Schubert, H., M. Andersson, and P. Snoeijs. 2006. Relationship Between Photosynthesis and Non-Photochemical Quenching of Chlorophyll Fluorescence in Two Red Algae with Different Carotenoid Compositions. Marine Biology, 149: 1003-1013

53. Semedi, B., Da Kosta and M. Mahmudi. 2016. Feasibility of Seaweed (Kapaphycus alvarezii) Maricultur Using Geografic Information System In Hading Bay, East Flores Indonesia. Journal of Natural Environment and pollution Technology,15(4): 1347-1349.

54. Sterman, T. N. 1988. Spectrophotometric and Fluorometric Chlorophyll Analysis. In: Lobban, S. C., D.J. Chapman and B. P. Kremer. Experimental Phycology, A Laboratory Manual Cambridge University Press. New York. Pp. 35-39.

55. Sulistiani, E., D.T. Soelistyowati, and S. A. Yani. 2011. Thallus Regeneration from Callus of Cottonii Seaweed (Kappaphycus alvarezii Doty). Research Report 2011. SEAMEO BIOTROP. Bogor.

56. Suzuki, A. and D. B Knaff. 2005. Glutamate Synthase: Structural, Mechanistic and Regulatory Properties, and Role in the Amino Acid Metabolism. Photosynthesis Research, 83: 191-217. 
57. Thirumaran, G. and P. Anantharaman. 2009. Daily Growth Rate of Field Farming Seaweed Kappaphycus alvarezii (Doty) Doty ex P. Silva in Vellar Estuary. World Journal of Fish and Marine Sciences, 1(3): 144-153.

58. Vanitha, A. and S. Chandra. 2012. Studies on Photosynthetic Pigments of Some Red Algae of Covelong, Chennai (India). International Journal of Current Science: 149-154.

59. Yaronskaya, E., I. Vershilovskaya, Y. Poers, A. E. Alawady, N. Averina, and B. Grimm. 2006. Cytokinin Effects on Tetrapyrrole Biosynthesis And Photosynthetic Activity in Barley Seedlings. Planta, 224: 700-709.

60. Yocum, C. S. and L. R. Blinks. 1957. Light Induced Efficiency and Pigment Alteration In Red Algae. The Journal of General Physiology, 41: 1113-1117.

61. Yokoya, N. S., O. Necchi, A. P. Martins, S. F. Gonzalez, and E. M. Plastino. 2007. Growth Responses and Photosynthetic Characteristics of Wild and Pycoerythrin-Deficient Strains of Hypnea musciformis (Rhodophyta). Journal of Applied Phycology, 19: 197-205

62. Yong, W. T. L., S. H. Ting, W. L. Chin, K. F. Rodrigues, and A. Anton. 2011. In vitro Micropropagation of Eucheuma Seaweeds. 2nd International Conference on Biotechnology and Food Science IPCBEE, 7: 58-60

63. Yong, W. T. L., J. Y. Y. Chin, V. Y. Thien, and S. Yasir. 2014. Evaluation of Growth Rate and Semi-Refined Carrageenan Properties of Tissue-Cultured Kappaphycus alvarezii (Rhodophyta, Gigartinales). Phycological Research, 62: 316-321

64. Yong, Y. S., W. T. L. Yong, V. Y. Thien, S. E. Ng, A. Anton, and S. Yasir. 2015. Acclimatization of Micropropagated Kappaphycus alvarezii (Doty) Doty ex Silva (Rhodophyta, Solieriaceae) in Outdoor Nursery System. Journal of Applied Phycology, 27: 413-419

65. Zhao, S. and P. He. 2009. Effects of Light Intensity and Salinity on Growth of Kappaphycus alvarezii. Journal of Tropical Oceanography, 28: 24-29.

66. Zhou, Y., H. Yang, H. Haiyan, L. Ying, M. Yuze, Z. Hua, X. Xinling, and Z. Fusui. 2006. Bioremediation Potential of the Macroalga Gracilaria lemaneiformis (Rhodophyta) Integrated into Fed Fish Culture in Coastal Waters of Nort China. Aquaculture, 252: 264276. 